\title{
CAPITAL INTENSIVE CLEAN ENERGY PROJECTS: SOMECOSTS, BENEFITS AND CHALLENGES OF USING PUBLIC-PRIVATE PARTNERSHIPS
}

\author{
Hilmar Pór Hilmarsson ${ }^{1}$
}

University of Akureyri (Iceland)

\begin{abstract}
Geothermal and hydropower projects tend to be capital intensive and with long repayment periods. These projects can be challenging, especially in developing and emerging countries in transition often characterized by changing and unpredictable political and business environments. Developing and emerging countries are eligible for support from international financial institutions (IFIs) such as the World Bank Group and regional development banks ${ }^{2}$ and can also receive assistance from bilateral donor institutions. PPPs enable pooling of public, private and donor funds for clean energy investment. A well designed PPP can be a venue for scaling up funding for clean energy investment internationally. However, little point exists in forming PPPs if, for example, the private sector partner captures most or all the benefits, or if the government keeps changing the rules of the game resulting in a non-viable project. The focus of this article is on PPPs, potential benefits and challenges for host governments and various partners, including the private sector, bilateral donors, and multilateral institutions such as IFIs. When disputes occur between the private sector and host governments, IFIs can potentially play an important role in resolving disputes and help ensure the fair sharing of the risks and the rewards of the PPP for all the parties involved. The objective of this article is to review some recent theoretical research recently done on PPP, potential benefits as well as some challenges using this model in developing and emerging countries.

KEYWORDS: hydro- and geothermal energy projects, public-private partnerships, international and national financial institutions.
\end{abstract}

JEL CODES: F30, G22, P18, Q40.

DOI:

\section{Introduction}

Clean energy investments such as geothermal and hydropower projects tend to be large, capital intensive and with long repayment periods. Construction of such projects is important in developing and emerging countries for environmental reason and as part of the battle against climate change. Because of their long term nature, these investments are challenging in economies that are in transition and are often characterized by a changing and unpredictable political situation and unfavourable business environments. For geothermal projects, several models can be used to mobilize capital and cover the resource risks. These include, for example: (i) an enterprise in public ownership, (ii) a private company developer and (iii) a public-private partnership (PPP). In the first model, a public sector company would typically undertake the whole project, including the resource risks. This could be a combination of national and municipal authorities such as in the case of Iceland. In the second model, a private sector developer might be a large company with a strong balance sheet as in the case of Chevron in the Philippines. In this case the private company has the financial

1 Hilmar Pór Hilmarsson - PhD, professor, School of Business and Science, University of Akureyri, Iceland Scientific interests: clean energy investments, finance, emerging and developing economies

E-mail: hilmar@unak.is

Tel. +3548498380

2 Such as the African Development Bank, the Asian Development Bank, European Bank for Reconstruction and Development and the Inter-American Development Bank. 
capacity to undertake the whole project. In the third model the public and private sectors work in partnership, i.e., a public-private partnership (PPP).

The objective of the article is to analyse potential benefits and challenges of the third model, i.e., the use of PPPs for capital intensive clean energy projects in developing and emerging countries. This includes host government cooperation with the private sector (domestic and foreign), and can also involve other players such as international and bilateral financial institutions. This article reviews some recent theoretical research recently done on PPP. Methods used in the article are: analysis and synthesis. Among the sources of evidence used for the analysis is secondary data, including analytical reports and scholarly literature.

\section{Public-private partnerships}

What exactly is a public-private partnership? Many different definitions are used for PPPs by different individuals and institutions. One definition is that "any public sector service provided partially or wholly by the private sector" (Delmon, 2009: 601). Another definition is "co-operative institutional arrangements between public and private sector actors" (Hodge, Greve, 2009: 33). The World Bank has defined PPPs as "the transfer to the private sector of investment projects that traditionally have been executed or financed by the public sector" (World Bank, 2008: 93). The Organization for Economic Co-operation and Development has defined PPPs as "long term contractual arrangements between the government and a private partner whereby the latter delivers and funds public services using a capital asset, sharing the associated risks" (OECD, 2012: 18). Notably, the Organization for Economic Co-operation and Development and the World Bank definitions mention capital investment by the private sector. The other definitions are more general, highlighting service and cooperation.

\section{Benefits from using PPPs}

Why would governments of developing and emerging market economies want to cooperate with the private sector under a PPP arrangement? The answer is: for several reasons. A PPP can be a feasible option for governments because in most developing and many emerging countries the government has limited capacity to mobilize funds. This means that a partnership with the private sector can help the government obtain much-needed long term capital. The private sector may also possess technical knowledge that the public sector does not have and be a more efficient operator of power plants. In this case a public-private partnership can be formed to allow for a sharing of the risks and rewards from the project.

PPP can be a favoured model in developing and emerging markets and be beneficial if well designed and if risks and rewards are shared fairly. However, little point exists in forming PPPs if, for example, the private sector partner captures most or all the benefits, or if the government keeps changing the rules of the game resulting in a non-viable project.

With pressure on physical infrastructure and limited resources, governments of developing and emerging countries may want to cooperate with the private sector via a PPP to help finance, build, and/or operate public projects. While doing so, the government could at least in theory: (1) utilize the better skills and better management from the private sector that may lead to increased efficiency for the project in a competitive environment, (2) access private sector funds to undertake more projects than would be possible with public funds alone - this can contribute to fiscal stabilization, and increase investment and growth, (3) provide more affordable and better services to end-users, and (4) share risks with the private sector (see, for example, Leruth, 2009; de Palma et al., 2009; Estache, 2005).

Developing and emerging economies on the one hand and high-income economies on the other may have different reasons for participating in public-private partnerships. As O. Hart points out, "Policy makers frequently argue that PPPs are good because the private sector is a cheaper source of financing or insurance than the public sector." Furthermore, he emphasizes that "This thinking is strange for an economist since it is hard to imagine an agent that is more able to borrow or to provide insurance than the government (with 
its enormous powers of taxation)" (Hart, 2003: C75). L. A. Leruth also argues as "the government is often able to borrow at [an] almost risk-free rate (no credit risk), which gives it an advantage" (Leruth, 2009: 230).

These arguments may well be true in countries that enjoy strong creditworthiness (e.g., via AAA or other high credit rating status). The countries discussed in this article, however, are developing and emerging countries. They often have large unutilized energy resources and strong medium- or long-term demand for energy, but their creditworthiness is limited. Their nationals often have limited ability to pay for the services rendered to them and the government has weak capacity to force them to do so through taxation. Such governments can be risky partners for the private sector in a PPP. In this situation, efficient and effective risk allocation is the key to success, and the international community can play a constructive role, for example, through participation by IFIs, which can involve a variety of funding and mitigation instruments.

When discussing green infrastructure finance, the World Bank states that "the international community has recognized that the majority of new investment financing will need to come from private sources" (World Bank, 2012: 16). The World Bank's focus is on developing and emerging markets. This means that some sort of public-private partnerships will need to be formed for a large share of clean energy investment in those markets in transition. This is a major challenge not only for the private sector, but also for participating developing and emerging countries. Moreover, as the World Bank has stated, "developing a framework for improved collaboration between public and private sectors could greatly benefit green infrastructure financing mechanisms" (World Bank, 2012: 6).

Interest in PPPs is growing among Asian countries, including a notably prominent market in China. The Association of Southeast Asian Nations (ASEAN) for example recently stated that "PPPs are seen to be beneficial in meeting ASEAN infrastructure needs, estimated by the Asian Development Bank at USD 60 billion per annum. Private participation in infrastructure provision can enhance existing public capacity in providing economic (e.g., transport, telecommunication, power, water and sanitation) and social (e.g., health and education) infrastructures" (ASEAN, 2014). Great need is also present in other developing and emerging regions such as Africa and Latin America.

\section{Challenges to using PPPs}

According to the Public-Private Infrastructure Advisory Facility ${ }^{3}$ countries using the PPP model need to have: strong institutions, legal systems and rule of law, high standards of public and corporate governance, transparency, competition, protection of investments, enforcement of laws, and dispute resolution mechanisms (World Bank, 2015). This is an impressive list, but some would argue that it is unrealistic even for developed high income countries. If international financial institutions insisted that those criteria be satisfied before an investment could take place using the PPP model, very few places in the world would receive any private finance. This would especially be a challenge in developing Africa.

Because of this challenge, key international organizations such as ASEAN, the European Union, the International Monetary Fund, the United Nations, and the World Bank have formulated and displayed substantial policy documents on PPPs. A recent paper on PPPs shows that international organizations use roughly the same categories and conceptions of stages for what is needed to establish effective PPPs (Greve, 2015).

Multilateral as well as bilateral financial organizations can at least in theory be a catalyst in supporting PPP projects, including in the clean energy sector. Institutions such as the World Bank Group and regional development banks can, via their policy dialogue, assist governments when undertaking reforms needed for

\footnotetext{
The Public-Private Infrastructure Advisory Facility was created in 1999 to act as a catalyst to increase the private sector participation in emerging markets. It provides technical assistance to governments to support creation of a sound enabling environment for the provision of basic infrastructure services by the private sector. The Public-Private Infrastructure Advisory Facility is a multi-donor technical assistance facility, financed by 17 multilateral and bilateral donors: the Asian Development Bank, Australia, Austria, Canada, the European Bank for Reconstruction and Development, France, Germany, the International Finance Corporation, Italy, Japan, the Millennium Challenge Corporation, the Netherlands, Sweden, Switzerland, the United Kingdom, the United States, and the World Bank. Public-Private Infrastructure Advisory Facility funds are untied and grants are provided on a demand-driven basis. See further: http://www.ppiaf.org/node/23\#What\%20is\%20PPIAF
} 
effective use of the PPP model. IFI support can be important because developing and emerging countries often have limited capacity to negotiate with multinational enterprises. Since the Public-Private Infrastructure Advisory Facility is a multi-donor technical assistance facility, financed by 17 multilateral and bilateral donors, it can play an important role here.

But, as mentioned before, using the PPP model and working in partnership with IFIs and bilateral development institutions, can also come at a cost. A recent book published by the World Bank, entitled "Public Private Partnerships in Europe and Central Asia - Designing Crisis-Resilient Strategies and Bankable Projects", comments very cautiously that "working with these institutions may also lengthen the project development process, given specific requirements in terms of environmental and social safeguards requirements and stringent procurement procedures" (Cuttaree, Mandri-Perrott, 2011: 59). Another recent book also published by the World Bank entitled: "Doing a dam better: the Lao Peopless Democratic Republic and the story of Nam Theun 2 (NT2)", is more critical when discussing the World Bank cooperation with the private sector. The authors simply state that: "The bad news is that the World Bank is seen as a high-cost/high-hassle partner of last resort. There is therefore a critical need to reduce the costs the private sector incurs for doing business with the World Bank. Doing so will require the World Bank to better understand the constraints under which the private sector works" (Porter, Shivakumar, 2010: 22). These comments are especially notable given that the authors have both served as the World Bank country directors. J. Shivakumar, for example, played an important role in enabling the Nam Theun 2 hydropower project in Lao.

\section{The challenges of host government cooperation with the private sector}

PPPs are not only a challenge for the private sector. Cooperation with a private enterprise can also be a serious challenge for host governments in developing and emerging market economies, especially during times of economic and financial crisis. In their book, Making Foreign Investment Safe - Property Rights and National Sovereignty, L. T. Wells and R. Ahmed (2007) document a dramatic dispute between CalEnergy, an entity founded as a consulting and service company for geothermal power in North America, and the Indonesian government. This dispute resulted in a claim under official political risk insurance filed by CalEnergy and paid by the US government agency, the Overseas Private Investment Corporation. Less dramatic, but still consequential, was the dispute between Enron, then a private power developer, and the Indonesian government, that ended with the Multilateral Investment Guarantee Agency (MIGA), the insurance agency of the World Bank Group, paying out its first claim ever.

As L. T. Wells and R. Ahmed state, "The Indonesian experience with official political risk insurance has not been the only one that has made developing countries a bit wary. From the point of view of host countries, the new property rights system was not being very constructive. The moral hazard associated with the insurance surely had encouraged some investors to avoid renegotiation when economic crisis hit Indonesia and other countries. And Indonesians saw themselves as having few rights when CalEnergy filed a claim with [the Overseas Private Investment Corporation] or when [the Overseas Private Investment Corporation] sought reimbursement from Indonesia." (Wells, Ahmed, 2007: 246). Insurance can thus under certain conditions put the host government in a very difficult position vis-à-vis a private sector investor who is insured, in this case with the powerful US agency Overseas Private Investment Corporation. Moreover, L. T. Wells and R. Ahmed also criticize the public agencies providing guarantees as follows: "Further, and unlike many private insurers, public agencies appear to pay little attention to actual or potential moral hazards. If [the Overseas Private Investment Corporation] would insure only a smaller percentage of the equity, forcing more of the risk onto the investor, one aspect of moral hazard ought to decline. Second, allowing [the Overseas Private Investment Corporation] to seek something less than full reimbursement from host countries would reduce the perception that it faces no loss if it decides to pay claims" (Wells, Ahmed, 2007: 246).

In the case of the Enron dispute in Indonesia, MIGA paid Enron in the end. MIGA then demanded reimbursement from the government of Indonesia and got it. A good relationship with the World Bank Group, which MIGA is part of, must also have been considered important for the government of Indonesia because 
of other projects and programs that could be jeopardized in the event of an unresolved dispute. It is, however, questionable whether the World Bank Group should use its leverage in this way.

While the tensions between the government of Indonesia and MIGA did not run as high as in the case of the Overseas Private Investment Corporation, both were costly for the government of Indonesia in terms of money and international relations. In their concluding chapter, L. T. Wells and R. Ahmed raise doubts about whether the international system of property rights can accomplish its goal of encouraging foreign investment that is helpful for the host country. Nevertheless, and in spite of the serious problems that a host government can experience, they recognize the need for public-private partnerships when they state that "Meeting the huge infrastructure needs for development will surely require a mix of private investment, state investment, multilateral lending, hybrid arrangements, and very substantial aid money" (Wells, Ahmed, 2007: 283).

IFIs are well placed to mitigate risks at competitive prices. As L. T. Wells says, "Official insurance can be priced low, since the threat of sanctions by the organizations backing the insurance sharply reduce the chances of the events being insured against occurring" (Wells, 2005: 91).

Regional and global economic crises, such as those that struck Asia in 1997/98, Argentina in 2001, and the whole world in 2008/09, can pose significant threats to the international investment regime. As Salacus (2010) states, "Countries under great stress, faced with potential social and political upheaval as a result of rapidly declining standards of living, often seek radical solutions and are impatient with international investment rules that may restrict their latitude of action. For example, during times of economic crisis, governments may be unwilling to grant national treatment to foreign investors, to avoid changing regulations in the name of "fair and equitable treatment," and to refrain from seizing vital national resources held by foreigners simply because they have made treaty promises not to expropriate. Thus Argentina, to cope with one the most serious economic and financial crisis in its history in 2001-2002, took a series of measures that foreign investors believed violated their legal rights and economic interests, resulting in the initiation of numerous investor-state arbitration claims" (Salacuse, 2010: 471). International financial institutions can play an important role in resolving disputes between host governments and foreign investors during economic and financial crises and they should make efforts to facilitate settlements that are fair for all parties involved.

\section{PPPs - allocating risks and sharing rewards}

In spite of the many potential problems and issues that can be associated with public-private cooperation, PPPs can be a feasible platform to fund infrastructure development and to increase the efficiency of public sector service delivery in developing and emerging economies. The PPP becomes a venue for the public and private sectors to cooperate on a project that would traditionally have been in the public domain. Infrastructure projects in the clean energy sector are often large, capital intensive and long term. Repayment periods are also often long. It can take a private investor 10 to 30 years to recover the investment and project returns. It is often challenging to maintain a good working relationship within a PPP for such a long time, while the local, regional and global environment may change dramatically during this period.

The private sector has for years been recognized as a significant financing source for meeting developing country investment requirements. However, financial markets remain largely untapped for this purpose and have yet to live up to their potential (Asian Development Bank, 2006). PPPs are one platform worth considering for the private sector to engage in infrastructure projects, including geothermal and hydropower projects. Private capital, bilateral and multilateral donor support, including IFIs, and public funds can be combined in a PPP project. A well designed policy and institutional framework for PPPs offers the opportunity to leverage and combine all three sources of financing and expertise without crowding out private investment. By forming a PPP both public and private sectors can share the risks and rewards of infrastructure projects.

Private sector funding and participation in clean energy projects is a challenge for various reasons. Among them is that the host government is often the only buyer of the electricity or hot water produced, i.e., it is the 
so called offtake purchaser ${ }^{4}$. Many developing and emerging countries with large clean energy potential have limited creditworthiness. They have low per capita income and are often going through economic and political transition. Developing and emerging countries can also be vulnerable during regional and global crises. In such cases the sponsors ${ }^{5}$ of a project may hesitate to inject funding because of uncertainty with the income stream from the investment. Lenders, including commercial investment banks, would also often hesitate to provide loans to such projects because of uncertainty whether the project company, whose income stream is at risk, can service its loans. Sponsors may also hesitate to provide equity capital.

To engage in cooperation, the public and private sectors can employ several different schemes ${ }^{6}$ including the so called BOT, i.e., Build-Operate-Transfer (International Monetary Fund, 2004). In BOT projects the private sector is responsible for financing, constructing and operating the project. Under this arrangement the host country grants a concession ${ }^{7}$, i.e., the right for a private firm to undertake a public sector project and operate it over an agreed period. When the concession expires the ownership of the project is transferred back to the party granting the concession ${ }^{8}$.

The partners typically involved in a BOT project are: the project company that undertakes the project, the host government (that can also be the offtake / power purchaser and guarantor), the shareholders, the lenders, the grantor, the construction contractor, the operator, the offtake purchaser/power purchaser, and the input supplier. Figure 1 below shows a typical PPP BOT contractual structure.

The project company uses the income stream from the project to service its debt and to pay returns to its investors 9 . The lenders to a BOT project might, for example, be commercial investment banks, IFIs and bilateral agencies. The IFIs could also serve as guarantors, e.g., for payment to the lenders, including commercial investment banks. National institutions such as export credit agencies, which support trade finance (goods and services), can also play a constructive role in reducing the risks taken by private sector investors, see e.g., T. Q. Dinh and H. P. Hilmarsson (2012a; 2012b; 2012c and 2013).

The lenders would typically be keen to manage their risks ${ }^{10}$ and would receive a fixed margin on their loan whereas the shareholders ${ }^{11}$ maximize the profits on their equity investment. In addition to obtaining funding for the project, the project company procures the design and coordinates the construction and operation of the project in line with the requirements of the concession agreement. Project company shareholders often include firms with construction and operation experience, and with offtake purchase capabilities (Delmon, 2009: 98).

The offtake purchase agreement secures the project payment stream. The offtake purchaser will be looking for guaranteed long term output from the project. The credit risk associated with the offtake purchaser will be of particular concern to the project company and the lenders. This is where guarantees from host governments or IFIs, including the World Bank, become important.

Critical to the design of PPPs is the way risks are allocated between the partners in the PPP. In fact, effective risk allocation is key to success in any PPP. A general principle is that risk should fall on the party that is abler to do something about it. Risks in PPPs tend to be allocated on the basis of commercial and negotiating strength. The stronger party will allocate risk that it does not want to bear to the weaker party. Efficient allocation of risk will generally result in a more successful and profitable project and will benefit each of the parties involved (Delmon, 2009).

4 An offtake purchaser is a purchaser of the product produced by a project. In case of a power project, the product produced is the electricity generated.

5 A sponsor of a project is a party wishing to develop or undertake a project. A sponsor would normally provide financial support for the project, e.g., early equity capital.

6 PPP schemes and modalities other than Build-Operate-Transfer (BOT) include, for example: Build-Own-Operate-Transfer (BOOT), Build-Rent-Own-Transfer (BROT), Build-Lease-Operate-Transfer (BLOT), Build-Transfer-Operate (BTO).

7 A concession is the right granted by the host government for a private company to undertake a public sector project and operate it over an agreed period.

8 For a comprehensive discussion on BOTs see, for example, Jeffrey Delmon's outstanding book on Private Sector Investment in Infrastructure (Delmon, 2009).

i.e., equity contributors to the project company.

10 i.e., they would only take measurable and measured risks.

11 i.e., equity holders in the project company. 


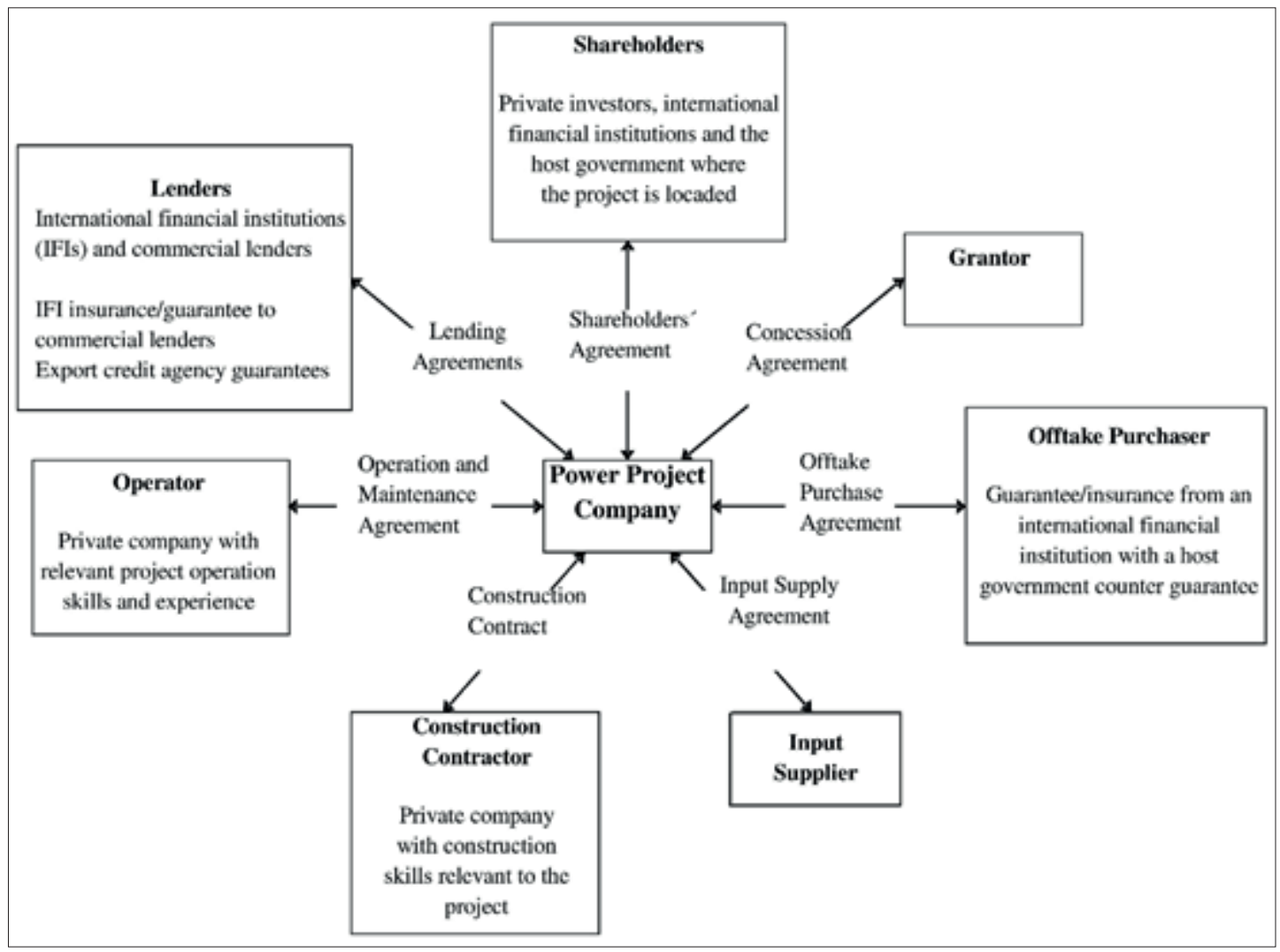

Figure 1. Typical PPP BOT contractual structure

Source: constructed by the author.

In order to minimize the market risk from the project company and the project lenders, an offtake purchase agreement, or in the case of a power project, a power purchase agreement, may be made. This is to create a secure payment stream which will be an important basis for financing the project. The offtake purchaser may also be the grantor, or a government entity such as a public utility, in which case the offtake purchase agreement and the concession agreement may be one and the same document (Delmon, 2009).

The lenders will want project risks to be allocated to project participants, i.e., the construction contractor and the operator but not the project company, which is their debtor. The project company will enter into a contract with the construction contractor in order to divest its obligations to the grantor to design, build, test, and commission the project. Completion risk for the project should be allocated to the construction contractor. In the case of a turnkey project, completion and performance risk should fall on the construction contractor.

If the main risks are associated with poor management of the service, shifting the risk to the operator could provide the right incentives to ensure that the project delivers. If risks are related to changes in policies, then the government should bear the risk. This is because the project company will not generally be able to manage political risk. The project company will ask the government to bear those risks, not necessarily to claim compensation at a future date but to pressure the government to avoid such risks and to minimize the probability that such risk events will occur. 


\section{Conclusions}

Geothermal and hydropower projects tend to be large, capital intensive and with long repayment periods. Projects with such a long duration are challenging, especially in developing and emerging market economies that are in transition and typically characterized by a changing and unpredictable political and business environments. PPPs enable pooling of public, private and donor funds for clean energy investment in developing and emerging market economies and those countries are eligible for support from international financial institutions such as the World Bank and regional development banks as well as form bilateral financial institutions. A well designed PPP can be a venue for scaling up funding for clean energy internationally. However, little point exists in forming PPPs if, for example, the private sector partner captures most or all the benefits, or if the government keeps changing the rules of the game resulting in a non-viable project.

Sharing the risks and the rewards in a fair and sustainable manner is important for the success of a PPP. Partners of PPPs can be vulnerable, including private partners as well as host governments. During the long duration of geothermal and hydropower projects, economic and financial crisis can hit. Those risks should be factored into the project. This can result in demands for higher returns for the private sector participants. Crises in East Asia as well as in Latin America can give valuable lessons to the private and public sectors, as well as to bilateral and multilateral providers of loans, equity and guarantees.

Reducing the risk of failure through the efficient project company's operations as well as good government policies is important for all parties involved. Shifting the risk to a weaker party is, however, questionable; e.g., if an insured private sector participant files a claim against the host government of a developing country without trying to resolve issues and then an insurer, such as an International Financial Institution (IFIs) or a national institution, files a reclaim against the host government without making credible efforts to resolve the dispute. IFIs and national institutions should avoid using their leverage vis-à-vis host government this way.

PPPs place a strong demand on host government capacity to communicate and negotiate both with private participants and IFIs when these are involved. Low government capacity is an obstacle when using the PPP framework, but one must keep in mind that a weak government is also less likely to be able to run a project with 100 percent public ownership efficiently. When disputes occur between the private sector and host governments, IFIs can and should play a role in resolving disputes and help ensure the fair sharing of the risks and the rewards of the PPP for all the parties involved.

\section{References}

ASEAN. (2014). ASEAN Principles for PPP Frameworks. Available at: http://asean.org/asean-welcomes-principlesfor-public-private-partnership-framework/ [Accessed January 19, 2017].

Asian Development Bank. (2006). Review of ADB's Credit Enhancement Operations. Available at: http://www.adb.org/ documents/review-adbs-credit-enhancement-operations [Accessed January 9, 2017].

Cuttaree, V., Mandri-Perrott, C. (2011). Public-Private Partnerships in Europe and Central Asia - Designing CrisisResilient Strategies and Bankable Projects. The World Bank.

Delmon, J. (2009). Private Sector Investment in Infrastructure. Project Finance, PPP Projects and Risk. 2nd edition. The Netherlands: Kluwer Law International.

De Palma, A., Leruth, L., Prunier, G. (2009). Towards a principal-agent based typology of risks in public-private partnerships. IMF Working Paper, WP/09/177. Available at: http://papers.ssrn.com/sol3/papers.cfm?abstract_id=1475518 [Accessed March 10, 2017].

Dinh, T. Q., Hilmarsson, H. P. (2012a). What are the Economic Justifications for the Existence of Export Credit Agencies and How Can They Facilitate Cross Border Trade to Emerging Market Economies? Journal of Regional Formation and Development Studies, Vol. 6, p. 15-25.

Dinh, T. Q., Hilmarsson, H. P. (2012b). Private Sector Export to Emerging Market Economies During Times of Crisis: How Can Export Credit Agencies Help? Review of International Comparative Management, Vol. 13, Issue 1, p. 167-180.

Dinh, T. Q., Hilmarsson, H. P. (2012c). How Can Private Companies Use the Financial Services and Risk Mitigation Instruments Offered by Export Credit Agencies in Emerging Markets? Proceedings. Project Development - Prac- 
tice and Perspectives. First International Scientific Conference on Project Management in the Baltic Countries. February 8-9, 2012, Riga, University of Latvia, p. 14-25.

Estache, A. (2005). PPI Partnerships versus PPI Divorces in Developing Countries (or Are We Switching from PPPI to PPDI?). Policy Research Working Paper, 3470. Washington: World Bank. Available at: http://documents.worldbank.org/curated/en/754011468778792772/pdf/WPS3470.pdf [Accessed March 11, 2017).

Greve, C. (2015). International Public-Private Partnership Policies: Convergence in Themes from ASEAN, the European Union, IMF, OECD, the UN, and the World Bank? Cornell University, Cornell Program for Infrastructure New York City, 15-16 September, 2015. Available at: http://openarchive.cbs.dk/bitstream/handle/10398/9196/Grevepaper-NYC-PPP-conference-2015.pdf?sequence=1 [Accessed January 20, 2017].

Hart, O. (2003). Incomplete Contracts and Public Ownership: Remarks, and an Application to Public-Private Partnerships. Economic Journal, Vol. 113, p. 69-76. Available at: http://scholar.harvard.edu/files/hart/files/incompletecontractsandpublicownershipej.pdf [Accessed March 5, 2017].

Hilmarsson, H. P., Dinh, T. Q. (2013). Export Credit Agencies, Cross Border Trade, Times of Crisis, and Increased Value Added in Emerging Economies Industrial Sectors. Conference article presented at the 55th Annual Meeting of the Academy of International Business, July 3 to 6, 2013, Istanbul, Turkey.

Hodge, G. A., Greve, C. (2009). PPPs: The Passage of Time Permits a Sober Reflection. Institute of Economic Affairs, Vol. 29, Issue 1, p. 33-39. Oxford: Blackwell Publishing.

International Monetary Fund. (2004). Public Private Partnerships. International Monetary Fund Washington, DC. Available at: http://www.imf.org/external/np/fad/2004/pifp/eng/031204.pdf [Accessed January 15, 2017].

Leruth, L. E. (2009). Public-Private Cooperation in Infrastructure Development: A Principal-Agent Story of Contingent Liabilities, Fiscal Risks, and Other (Un)pleasant Surprises. Springer Science + Business Media, LLC. Available at: http://link.springer.com/article/10.1007\%2Fs11067-009-9112-0

[Accessed January 15, 2017].

Organization for Economic Cooperation and Development. (2012). Recommendations of the Council on Principles for Public Governance of Public-Private Partnerships. Paris: OECD. Available at: https://www.oecd.org/governance/ budgeting/PPP-Recommendation.pdf [Accessed January 20, 2017].

Porter, I. C., Shivakumar, J. (2010). Doing a dam better: the Lao People's Democratic Republic and the story of Nam Theun 2 (NT2). Washington D.C.: The World Bank. Available at: http://documents.worldbank.org/curated/ en/2010/01/13240425/doing-dam-better-lao-peoples-democratic-republic-story-nam-theun-2-nt2 [Accessed January 2, 2017].

Salacuse, J. W. (2010). The Emerging Global Regime for Investments. Harvard International Law Journal, Vol. 51, No. 2, Summer. Available at: http://www.harvardilj.org/wp-content/uploads/2010/09/HILJ_51-2_Salacuse.pdf [Accessed January 2, 2017].

Wells, L. T., Ahmed, R. (2007). Making Foreign Investment Safe - Property Rights and National Sovereignty. Oxford University Press.

Wells, L. T. (2005). The New International Property Rights. Can the Foreign Investor Rely on Them? In: T. H. Moran, G. T. West (eds.). International Political Risk Management. Looking to the Future. The World Bank Group - Multilateral Investment Guarantee Agency.

World Bank. (2012). Green Infrastructure Finance - Framework Report. East Asia and Pacific Region/East Asia Infrastructure Unit (EASIN).

World Bank. (2015). The World Bank Group A to Z. The International Bank for Reconstruction and Development / The World Bank, Washington. DC 20433.

World Bank. (2008). Capital Matters. Vietnam Consultative Group Meeting Hanoi. Available at: http://siteresources. worldbank.org/INTVIETNAM/Resources/387318-1235543674588/vn_devreport09_front.pdf [Accessed January 7, 2017].

Yin, R. K. (2009). Case Study Research. Design and Methods. 4th ed., Vol. 5. California: SAGE Inc. 


\title{
PRADINIAM KAPITALUI REIKLÜS ŠVARIOS ENERGIJOS PROJEKTAI: SĄNAUDOS, NAUDA IR IŠŠ ŪKIAI, NAUDOJANTIS VIEŠOJO IR PRIVAČIOJO SEKTORIAUS PART NER Y T T E
}

\author{
Hilmar Pór Hilmarsson \\ Akureyri universitetas (Islandija)
}

\section{Santrauka}

Siekiant vykdyti geoterminius ir hidroenerginius projektus, dažnai reikia turèti daug pradinio kapitalo investicijų, jų atsipirkimo laikotarpis yra gana ilgas. Šie projektai gali kelti iššūkių, ypač besivystančiose ir besiformuojančiose šalyse, kurios dažnai pasižymi besikeičiančia ir nenuspejjama politine bei verslo aplinka. Besivystančios ir besiformuojančios valstybès turi teisę gauti paramą iš tarptautinių finansinių institucijų (TFI), pavyzdžiui, Pasaulio Banko grupès ir regioninių plètros bankų, be to, gali gauti pagalbą iš dvišalių donoru įstaigų.

Viešojo ir privačiojo sektorių partnerystė (VPSP) leidžia sutelkti viešųjų, privačių ir donorų lèšas ir investuoti jas ị švarią energetiką. Gerai suformuota VPSP gali būti būdas internacionaliai didinti švarios energijos investicijų finansavimą. Tačiau nebūtina kurti VPSP, jeigu, pavyzdžiui, privačiojo sektoriaus partneris gauna visą naudą arba valdžia nuolat keičia žaidimo taisykles, nes tai sukuria negyvybingą ir nepraktišką projektą. Šio straipsnio dèmesys sutelktas ị VPSP potencialią naudą ir potencialius sunkumus priimančioms valstybėms bei jų partneriams, ịtraukiant privatujị sektorių, dvišalius donorus, daugiašales institucijas, kaip TFI. Kai ginčų kyla tarp privačiojo sektoriaus ir priimančiosios vyriausybės, TFI, sprendžiant ginčus ir padedant užtikrinti sąžiningą dalijimąsi rizika bei VPSP naudą visoms dalyvaujančioms šalims, gali vaidinti svarbų vaidmenị. Šio straipsnio tikslas - peržvelgti kai kuriuos naujausius teorinius tyrimus VPSP tematika, išskiriant potencialią naudą ir iššǔkius, taikant privačiojo ir viešojo kapitalo partnerystès modeli besikuriančiose ir besivystančiose šalyse.

Svarbu sąžiningai pasidalinti rizika ir nauda, siekiant sèkmingos VPSP. VPSP partneriai gali būti pažeidžiami - tiek privatūs, tiek priimančios valdžios. Vykdant ilgalaikius hidroenerginius ir geoterminius projektus, gali kilti ekonominių arba finansinių krizių. İ šią riziką turètų būti atsižvelgta vykdant projektą. Tai gali lemti didesnius grąžos reikalavimus iš privačiojo sektoriaus dalyvių. Rytų Azijos ir Lotynų Amerikos krizių pavyzdžiai privatuji ir viešajj sektorius bei dvišalius ir daugiašalius paskolų, nuosavo kapitalo ir garantijų teikejjus gali išmokyti naudingų dalykų.

Mažinti nesėkmès riziką, siekiant veiksmingos projekto įmonės veiklos ir valdymo politikos, svarbu visoms dalyvaujančioms šalims. Tačiau perkelti riziką silpnesnei šaliai yra kvescionuotina praktika, pavyzdžiui, jeigu apdraustas privačiojo sektoriaus dalyvis paduoda ieškinị prieš priimančią besivystančią valstybę, net nepabandęs spręsti problemos, draudikas, kaip TFI arba nacionalinė institucija, nurodo priimančiai šaliai atlyginti nuostolius, net nebandydama spręsti nesutarimo.

PAGRINDINIAI ŽODŽIAI: hidro- ir geoterminès energijos projektai, viešoji ir privačioji partnerystė, internacionalinès ir nacionalinés finansinès institucijos.

JEL KLASIFIKACIJA: F30, G22, P18, Q40

Received: 2017.03.15

Revised: 2017.04.13

Accepted: 2017.04.22 